\title{
MADRASAH DAN SEKOLAH ISLAM ELIT DI INDONESIA
}

\author{
Abdul Basyit \\ basyit71@yahoo.com \\ (Dosen Fakultas Agama Islam, Universitas Muhammadiyah Tangerang)
}

\begin{abstract}
Abstrak:
Menguatnya posisi lembaga pendidikan Islam tidak lepaskan dari upaya dinamika internal dalam tubuh pendidikan Islam berupa modernisasi, yang berkesinambungan dengan modernisasi Islam. Faktor yang menumbuhkembangkan keberadaan sekolah dan madrasah elit. Pertama, kesadaran untuk mendesain system pendidikan unggul. Kedua, menurunnya proses dan hasil pendidikan di sekolah-sekolah umum. Ketiga, skeptis terhadap proses dan hasil pendidikan pada pesantren dan madrasah. Keempat, peningkatan kemampuan ekonomi. Kelima, dukungan pemerintah dalam otonomi pendidikan swasta dan program pemerintah dalam upaya "internasionalisasi" semua level pendidikan di Indonesia.
\end{abstract}

\section{Kata Kunci: Madrasah, Sekolah, Islam, Elit.}

\section{A. Pendahuluan}

Perkembangan lembaga pendidikan Islam modern di Indonesia, akhir-akhir ini mendapatkan imbangan informasi dari sisi "kecurigaan" atau sisi jurnalisme kotor (dirty journalism). Hal ini disebabkan oleh intensitas pemberitaan mass media Barat (Amerika dan Eropa) mengenai lembaga pendidikan tradisional di dunia islam, khususnya madrasah dan Pesantren dalam konteks Indonesia.

Berbagai media Barat mengarahkan kecurigaan kepada lembaga pendidikan Islam tersebut (madrasah dan pesantren), sebagai "tempat penyemaian benih-benih radikalisme" (seeds of radicalism) yang berujung pada jihadisme, sebuah istilah lain yang sering digunakan media massa Barat untuk menyebut "terorisme". Mengenai hal ini, Robert W. Hefner menuliskan: "Sejak Taliban memasuki Kabul pada 1996, media Barat bergulat memecahkan pertanyaan tentang watak radikalisme Islam dan hubungannya dengan pendidikan agama. Sejumlah

${ }^{1}$ Azyumardi Azra, "Wajah Baru Pendidikan Islam", dalam Asrori S. Karni, Etos Studi Kaum Santri: Wajah Baru Pendidikan Islam, (Bandung: Mizan, 2009), h. xii komentator dengan cepat menyebut sumber kebangkitan kaum radikal tersebut pada madrasah, yakni sekolah agama yang diabdikan untuk studi tradisi keilmuan Islam. Sebuah artikel yang banyak dikutip pada New York Times Magazine melaporkan (bahwa) terdapat sekitar satu juta murid belajar pada 10.000 madrasah di Pakistan; dan Islam militan berada pada jantung kebanyakan madrasah itu. Banyak komentator lain mencurigai adanya semangat yang sama militannya berada pada jantung pendidikan madrasah di mana-mana. $^{2}$

Setelah menceritakan mengenai persepsi dominan Barat tentang kaitan madrasah dengan terorisme, Robert W. Hefner, yang terkenal sebagai Indonesianis, menolak pengidentikan total

\footnotetext{
${ }^{2}$ Robert W. Hefner, "Introduction: The Culture, Politics, and Future of Muslim Education", dalam Robert W. Hefner dan Qasim Zaman (ed), Schooling Islam, The Culture and Politics of Modern Islamic Education, (Princeton University Press, 2007). Hal serupa dikemukakan oleh Mumtaz Ahmad dalam "Madrasah Reform and Perspectives: Islamic Tertiary Education in Pakistan" dan "Views Form Madrasah: Islamic Education in Bangladesh" (NBR Project Report, 2009).
} 
antara madrasah sebagai seed of radicalism. Hefner menunjukkan bahwa realitas madrasah bersifat kompleks, tidak sederhana, dan tidak seragam. Menurutnya, terdapat sejumlah madrasah [dan pesantren] yang justeru anti-radikalisme dan anti teror. ${ }^{3}$

Salah satu negara yang berhasil malakukan transformasi madrasah adalah Indoensia, sebagaimana dibuktikan oleh Azyumardi Azra, Dina Afriyanti, dan Robert W. Hefner. Hanya saja, menurut Azyumardi Azra, hasil signifikan proses tranformasi madrasah di Indonesia ini kurang diketahui dan disadari oleh banyak kalangan dunia pendidikan Indonesia sendiri maupun para pengamat dan peneliti asing. Karena itu, pemahaman dan apresiasi lebih baik terhadap madrasah pastilah perlu dikembangkan terus, baik di dalam maupun di luar negeri. ${ }^{4}$

Gerak transformatif madrasah tidaklah sendirian, karena ada lembaga pendidikan Islam formal lainnya yang bersamaan bertransformasi, yakni sekolah Islam. Selain keduanya, pesantren tidak boleh dilupakan, karena ternyata pesantren pun memiliki sejarah perubahan yang unik dan menarik. Karenanya, perkembangan lembaga pendidikan Islam di Indonesia, baik madrasah, sekolah Islam, maupun pesantren memanglah sangatlah menarik dan memiliki keunikannya tersendiri.

Sejarah panjang lembaga pendidikan Islam ini, sebelum kemunculannya dengan "wajah baru", identik dengan sejarah keterpinggiran dan keterbelakangan. Tetapi sejak awal tahun 1970-an, yakni masa Prof. Dr. A. Mukti Ali menjabat Menteri Agama RI, lembaga pendidikan Islam seakan-akan mempunyai "titik picu" untuk

\footnotetext{
${ }^{3}$ Pandangan serupa dikemukakan oleh Farish A. Noor, Yonginder Sikand, dan Martin van Bruinessen dalam Madrasa In Asia: Political Activism and Transnasional Linkage, (Amsterdam University Press, 2008)

${ }^{4}$ Azra, "Wajah Baru Pendidikan Islam", h. xvi
}

merintis jalan ke arah transformasi, akselerasi, dan menuju momentumnya. Momentum itu, menurut Azyumardi Azra, adalah mainstreaming of Islamic Education, yakni pengarusutamaan pendidikan Islam; tegasnya, dari yang semula berada di pingiran menuju ke "tengah", ke dalam arus utama pendidikan nasional Indonesia secara keseluruhan.

Ketiganya memiliki struktur, fungsi, dan perannnya masing-masing dalam upayanya mengabdikan diri peningkatan kualitas pendidikan di Indonesia. Pada sisi lain, ketiganya memiliki kontribusinya tersendiri dimensi kemanusian. Namun demikian, ketiganya memiliki visi dan misi yang sama, yakni peningkatan kualitas kehidupan masyarakat Indonesia, khususnya umat Islam, dalam upayanya menjalani kompetisi kehidupan di dunia global dan internasional.

\section{B. Modernisasi Lembaga-Lembaga Pendidikan Islam Indonesia}

Dinamika pendidikan Islam, beberapa tahun terakhir, ditandai gejala makin besarnya peran Negara sebagai motor penggerak, yang secara gradual menggeser dominasi masyarakat. ${ }^{5}$ Peran utamanya adalah kebijakan sistem pendidikan, dan terutama alokasi anggaran, dan berbagai program pemberdayaan. Fenomena menguatnya "sokongan" kekuasaan Negara dalam lingkungan pendidikan Islam memiliki signifikansinya tersendiri, dibanding dengan pendidikan umum, karena selama pemerintahan Belanda, Jepang, orde lama, dan awal orde baru, lembaga pendidikan Islam ditempatkan pada posisi marjinal, terbelakang, dan dipandang sebagai oposisi.

Menguatnya posisi lembaga pendidikan Islam tidak dapat dilepaskan dari upaya dinamika internal dalam tubuh

\footnotetext{
${ }^{5}$ Asrori S. Karni, Etos Studi Kaum Santri, h.
} 
pendidikan Islam berupa modernisasi, yang berkesinambungan dengan modernisasi Islam. Modernisasi Islam dalam berbagai aspeknya, yang berawal dari pembaharuan pemikiran Islam, telah membawa dampak positif pada upaya modernisasi kelembagaan pendidikan Islam. Gagasan modernism Islam yang menemukan momentumnya sejak awal abad ke-20, pada lapangan pendidikan direalisassikan dengan pembentukan lembaga-lembaga pendidikan modern yang diadopsi dari sisetm pendidikan kolonial Belanda. Pemprakarsa pertama dalam hal ini adalah organisasi-organisasi "modernis" Islam, seperti Jami'at Khair, al-Irsyad, Muhammadiyah, dan lain-lain.

Menurut Azyumardi Azra, pada awal perkembangan adopsi gagasan modernisasi pendidikan Islam ini setidak-tidaknya terdapat dua kecendrungan pokok dalam eksperimentasi organisasi-organisasi Islam tersebut. ${ }^{6}$ Pertama, adalah adopsi sistem dan lembaga pendidikan modern secara hampir menyeluruh. Titik tolak modernism pendidikan Islam di sini adalah sistem dan kelembagaan pendidikan modern Belanda, bukan sistem dan lembaga pendidikan Islam tradisional. Eksperimen ini terlihat dilakukan oleh Abdullah Ahmad dengan madrasah Adabiyah-nya, yang kemudian berubah namanya menjadi Sekolah Adabiyah (1915). Kurikulum yang diterapkannya mengadopsi kurikulum HIS (sekolah dasar yang dibuat Belanda); perbedaannya hanyalah pada keberadaan tambahan matpel agama selama 2 jam. Sama halnya dengan Sekolah Adabiyyah, sekolah-sekolah yang didirikan oleh Muhammadiyah pun, secara konsisten dan menyeluruh, mengadopsi kurikulum sekolah-sekola ala Belanda, seperti MULO, HIS, dan lain-lain. Yang membedakannya pun adalah penambahan

\footnotetext{
${ }^{6}$ Azyumardi Azra, Pendidikan Islam: Tradisi dan Modernisasi Menuju Milenium Baru, (Jakarta: Logos, 2003), cetakan ke-5, h. 37
}

"pendidikan agama" (persisnya adalah met de Qur'an) ke dalam kurikulumnya. Karena itu, kedua sekolah ini, pada dasarnya dapat dikatakan sebagai "Sekolah umum (Belanda) plus". Selebihnya, Muhammadiyahpun melakukan eksperimen dengan sistem dan kelembagaan madrasah modern dengan mendirikan Madrasah Muallimin dan Madrasah Muallimat. Tetapi serupa dengan kelembagaan sekolah-sekolahnya, madrasah-madrasah yang didirikan Muhammadiyahpun dikembangkan dengan mendasarkan diri pada kelembagaan pendidikan modern (Belanda), atau tidak menjadikan sistem dan kelembagaan pendidikan Islam tradisional sebagai basisnya. $^{7}$ Pada pihak lain, terdapat eksperimen yang bertitik tolak justeru dari sistem dan kelembagaan pendidikan Islam itu sendiri. Di sini lembaga pendidikan Islam yang sudah ada sejak waktu lama dimodernisir. Misalnya sistem pendidikan pondok dan pesantren, madrasah, atau surau, yang secara tradisional merupakan indigenous, dimodernisasi dengan mengadopsi aspek-aspek tertentu dari sistem pendidikan modern, khususnya dalam kandungan kurikulum, teknik dan metode pngajaran, materi PBM, dan tekhnik evaluasi PBM.

Eksperimen semacam ini misalnya dilakukan oleh Pesantren Manbaul Ulum di Surakarta pada tahun 1906. Sebagaimana pesantren lainnya, Manbaul Ulum mempelajari berbagai keilmuan tradisional Islam, seperti Qur'an, Hadits, fiqh, tasawuf dan bahasa Arab. Selebihnya, pesantren ini mengajarkan manthiq, aljabar, ilmu falak, serta memasukkan matpel membaca dan menulis huruf latin serta berhitung. Pesantren yang paling awal melakukan modernisasi adalah Gontor Ponorogo.

\section{Madrasah}

Virginia Hooker menyebutkan bahwa berabad-abad sebelum Negara-

${ }^{7}$ Azra, Pendidikan Islam, h. 37 
bangsa (nation-state) menjadi model bagi sebagian besar kekuatan politik modern, masyarakat muslim dengan model khilafah Islamiyyahnya sebagai kesatuan kekuatan politik telah mengembangkan model pendidikan formalnya untuk anak-anak mereka. Salah satunya adalah madrasah, yang umumnya dipimpin oleh seorang ulama karismatik, diakui otoritas keilmuan, pengetahuan, dan teladan positif perilaku kesahariannya. Sistem pendidikan ini dibangun, umumnya, di atas swadaya dan swadana masyarakat muslim, melalui wakaf, hibah, dan dana sumbangan wali murid dan komunitas lokal di sekitarnya. ${ }^{8}$

Madrasah inilah yang umumnya menjadi model pendidikan masyarakat muslim dari zaman ke zaman, termasuk di Indonesia. Dengan demikian, secara kelembagaan, madrasah yang ada di Indonesia merupakan kelanjutan dari sistem pendidikan Islam klasik dan pertengahan. Kajian dari George Makdisi (1981), Jonathan Berkey (1992), dan Michael Chamberlain (1994) menunjukkan kesinambungan dan perubahan kelembagan dan kurikulum madrasah dari zaman ke zaman. Berkey bahkan menyebutkan bahwa, bagi umat Islam, madrasah tidak hanya merupakan lembaga pendidikan saja, tetapi memaikan peran signifikan bagi identitas muslim. ${ }^{9}$

Madrasah khususnya tipikal klasik, yang hampir sebangun dengan pesantren salafi (tradisional), yang ada di berbagai Negara termasuk Indonesia, jelas merupakan salah satu kelembagaan warisan khazanah klasik. Madrasah jenis ini merupakan salah satu kelembagaan

\footnotetext{
${ }^{8}$ Virginia Hooker, "New Undestanding of Islamic Education in Indonesia", dalam Asrori S. Karni, Etos Studi Kaum Santri: Wajah Baru Pendidikan Islam, (Bandung: Mizan, 2008), h. xxi.

${ }^{9}$ Jonathan Berkey, "Madrasas Medieval and Modern: Politics, Education, and the Problem of Muslim Identity”, dalam Robert W. Hefner dan Qasim Zaman (ed), Schooling Islam, The Culture and Politics of Modern Islamic Education, (Princeton University Press, 2007)
}

otoritas ulama. Keberadaannya masih memainkan peranan penting pada masyarakat Muslim. Misalnya, Madrasah Deoband di Asia Selatan, yang menghadapi tantangan intra-muslim dan lingkungan lebih luas, ${ }^{10}$ sebagaimana keberadaan madrasah di lingkungan muslim minoritas seperti ditunjukkan oleh Barbara Metcalf $^{11}$ dan Peter Mandaville. ${ }^{12}$

Madrasah mengalami transformasi berkesinambungan dan berkelanjutan dalam upayanya menghadapi berbagai tantangan internal dan eksternal yang ada. Kemampuan bertahan dan bertransformasi inilah yang membuat madrasah, yang kini masih ada, dapat bertahan dan berkembang. Dale Eickelman, dalam studinya tentang madrasah di Marocco, menyebutkan bahwa madrasah-madrasah tradisional di Marocco gagal merespon perubahan sehingga peran publiknya terus memudar. Sementara, menurutnya, madresse yang berada di Turki memiliki kemampuan untuk bertahan dan betransformasi, hingga mampu bertahan sekalipun dalam dominasi pendidikan sekuler Turki. Keberadaan madresse, yang sempat dihapuskan oleh Kemal Pasya Ataturk pada tahun 1924, kini muncul dalam gerakan Nurculuk melalui sayap dan jaringan Fethullah Gullen telah mampu memodifikasi madresse sebagai pendidikan keagamaan alternative, yang sering disebut sebagai hidden medresse

\footnotetext{
${ }^{10}$ Muhammad Qasim Zaman, "Tradition and Authority in Deobandi Madrasas of South India", dalam Robert W. Hefner dan Qasim Zaman (ed), Schooling Islam, The Culture and Politics of Modern Islamic Education, (Princeton University Press, 2007)

${ }^{11}$ Barbara Metcalf menggambarkan keberadaan madrasah di lingkungan minoritas muslim India dalam "Madrasas and Minorities in Secular India" dalam Robert W. Hefner dan Qasim Zaman (ed), Schooling Islam, The Culture and Politics of Modern Islamic Education, (Princeton University Press, 2007).

${ }^{12}$ Peter Mandaville menggambarkan keberadaan Madrasah di tengah-tengah masyarakat muslim minoritas di Inggris.
} 
(madrasah terselubug). Pada sisi lain, Madrasah di Mali, sebagaimana diungkap oleh Louis Brenner, mengalami transformasi signifikan sehingga mampu bertahan sebagai institusi mediasi sosialkeagamaan.

Transformasi madrasah paling berhasil, menurut Azyumardi Azra, Dina Afriyanti, dan Robert W. Hefner justeru dapat dipastikan terjadi di Indonesia. Hanya saja, menurut Azyumardi Azra, tranformasi signifikan madrasah di Indonesia ini kurang diketahui dan disadari oleh banyak kalangan dunia pendidikan Indonesia sendiri maupun para pengamat dan peneliti asing. Karena itu, pemahaman dan apresiasi lebih baik terhadap madrasah pastilah perlu dikembangkan terus, baik di dalam maupun di luar negeri. ${ }^{13}$

Sejak Indonesia merdeka hingga kini, banyak madrasah yang kemudian mengkonversi diri ke dalam sistem pendidikan (kurikulum) yang berada dalam pembinaan dan pengawasan Kementrian Agama (Kemenag) Republik Indonesia. Secara perlahan, dari orde ke orde, seluruh sistem pendidikan madrasah dapat dipastikan berada on the track Kementrian Agama RI. Hanya saja keberadaan madrasah [sebagaimana pesantren), pada masa orde lama dan orde baru awal, identik dengan keterpinggiran dan keterbelakangan.

Transformasi madrasah ini bermula dari upaya Menteri Agama, A. Mukti Ali, pada tahun 1970 an, memperbaharui kurikulum madrasah, yang semula $100 \%$ berisi mata pelajaran (matpel) keagamaan, menjadi $70 \%$ matpel umum dan 30 matpel agama. Upaya ini membawa jalan pada upaya penyetaraan madrasah dengan sekolah umum, yang ditetapkan melalui UU sisdiknas no. 2 tahun 1989, yang kemudian direvisi oleh UU sisdiknas no. 20 tahun 2003. UU sisdiknas ini

\footnotetext{
${ }^{13}$ Azra, "Wajah Baru Pendidikan Islam", h.
}

merupakan titik tolak legislasi negara menutup gap (kesenjangan) antara madrasah dan sekolah umum.

Berdasarkan laporan Kemenag RI, hampir 97\% madrasah dikelola oleh swasta, yayasan, atau pesantren. Sejumlah madrasah negeri sebelumnya adalah rintisan masyarakat yang dinegerikan. Seluruh pondok pesantren dan madrasah diniyah juga swasta. Keberlangsungan madrasah (dan pondok pesantren) banyak ditopang oleh elemen masyarakat (atau pihak non-pemerintah), baik perorangan, yayasan, maupun Ormas Islam. Data ini perlu dikemukakan, karena berbeda dengan sekolah umum (negeri) yang sebagian besar $(65 \%)$ dikelola oleh Negara.

Secara kelembagaan, jenjang madrasah serupa dengan sekolah yang berada di bawah kemendiknas. Madrasah terdiri dari madrasah Ibtidaiyah (setara SD, 6 tahun), Madrasah Tsanawiyah (setara SMP, 3 tahun), dan Madrasah Aliyah (setara SMU, 3 tahun). Madrasah pun dapat diklasifikasikan juga sebagai madrasah negeri dan madrasah swasta. Dari segi kurikulum, madrasah pun mengikuti kurikulum yang ditetapkan oleh Undang-Undang Sistem Pendidikan Nasional (Sisdiknas) nomor 2 tahun 1989 dan nomor 20 tahun 2003. Berdasarkan pada undang-undang ini, madrasah memiliki kesetaraan dengan sekolah (umum). Perbedaannya hanya terletak pada penekanannya terhadap matpel agama Islam. Inilah yang menyebabkan madrasah diasumsikan "lebih Islami" daripada sekolah lainnya. Selebihnya, Kemenag RI pun berusaha merumuskan dan mengimplementasikan, apa yang disebut para ahli sebagai, "nuansa islam" dalam kurikulum. $^{14}$

Sejak dikeluarkannya UU Sisdiknas inilah, transformasi madrasah [dan

\footnotetext{
${ }^{14}$ Kemenag telah menghimpun sejumlah ahli untuk menulis sejumlah buku yang berkenaan dengan masing-masing matpel dengan "nuansa Islam".
} 
pesantren] menemukan momentumnya, sebagaimana dibuktikan Azyumardi Azra, Dina Afriyanti, dan Hefner. ${ }^{15}$ Indikator utama adalah semakin intensnya keterlibatan madrasah dalam pendidikan umum, pembangunan bangsa, dan kewargaan kultural (civil society). Perhatian Negara yang meningkat melalui keserupaan kebijakan, termasuk alokasi dana, menyuntikkan "darah segar" pada madrasah serta memicu dinamika baru yang tengah menggeliat dalam kancah pendidikan Islam. Dampak dari peluang baru kebijakan dan alokasi dana Negara pada pendidikan Islam, tidak hanya menyediakan akses lebih baik pada pendidikan Islam, tetapi juga telah mendorong peningkatan standard dan kualitas. Pendidikan sains dan teknologi di madrasah, misalnya, diuntungkan dengan adanya perhatian lebih besar, fasilitas lebih baik, dan staf pendidikn yang lebih berkualitas tinggi. ${ }^{16}$

Transformasi inilah yang kemudian dikenal sebagai mainstreaming (pengarusutamaan) madrasah (dan pendidikan Islam lainnya) ke dalam sistem pendidikan nasional. ${ }^{17}$ Hampir tidak ditemukan resistensi berarti terhadap upaya transformasi dan affirmasi Negara terhadap madrasah ini dari umat islam, sebagai pendiri, pemiliki, dan pengelola madrasah. Nyaris absennya resistensi ini berkaitan dengan adanya harapan yang sudah lama diperjuangan umat Islam untuk kesetaraan madrasah dengan sekolah umum, sehingga siswa-siswa madrasah dapat melanjutkan ke sekolah umum serta perguruan tinggi umum. Usaha ini jelas merupakan langkah

\footnotetext{
${ }^{15}$ Hefner dan Qasim Zaman (ed), Schooling Islam, The Culture and Politics of Modern Islamic Education, (Princeton University Press, 2007).

${ }^{16}$ Virginia Hooker, "New Undestanding of Islamic Education in Indonesia", dalam Asrori S. Karni, Etos Studi Kaum Santri: Wajah Baru Pendidikan Islam, (Bandung: Mizan, 2008), hlm. xxii.

${ }^{17}$ Azra, “Wajah Baru Pendidikan Islam”, h.
}

yang tidak dapat dimundurkan lagi (point of no return). ${ }^{8}$ Karenanya, Ahmad Tafsir menyebutkan bahwa fenomena kontemporer madrasah di Indonesia mengindikasikan "kemenangan politik pendidikan Islam di Indonesia". Karena, tidak ada pendidikan "berbasis agama", yang diakomodir dan dikeola oleh negara di Indonesia kecuali, sistem pendidikan madrasah, yang nota bene milik umat Islam.

Titik temu transformasi kelembagaan madrasah dan pesantren, justeru berakumulasi pada transformasi madrasah di lingkungan pesantren, sebagaimana ditunjukkan oleh Asrori S. Karni. ${ }^{19}$ Karenanya, tidaklah salah, apabila kemudian terdapat anggapan bahwa madrasah dan pesantren (serta lembaga pendidikan Islam lainnya) di Indonesia menempati ranking sistem pendidikan paling terbuka dan inovatif di dunia.

\section{Sekolah Islam}

Sekolah-sekolah Islam di Indonesia, dewasa ini, berada dalam pengawasan dan pembinaan Kementrian Pendidikan Nasional [Kemendiknas]. Mereka "meniru" model sekolah negeri yang ada di lingkungan Kemendiknas. Sebagaimana sekolah negeri, sekolah Islam terdiri dari a) pendidikan dasar enam tahun, yang secara kelembagaan dikenal sebagai sekolah dasar (SD) Islam, 2) pendidikan menengah pertama, yang dikenal sebagai Sekolah Menengah Pertama (SMP) Islam, dan 3) pendidikan menengah kedua, yang dikenal

\footnotetext{
${ }^{18}$ Azra, “Wajah Baru Pendidikan Islam”, h. xvi

${ }^{19}$ Asrori S. Karni, Etos Studi Kaum Santri: Wajah Baru Pendidikan Islam, (Bandung: Mizan, 2008). Karya ini menjelaskan berbagai pola, dinamika, dan prisma transformasi madrasah dan lembaga pendidikan Islam lainnya. Temuan-temuan yang ada dalam karya Asrori S. Karni ini banyak mengkitisi dan merevisi berbagai persepsi tipikal pemerhati dan peneliti sebelumnya tentang berbagai lembaga pendidikan Islam di Indonesia.
} 
dengan Sekolah Menengah Umum (SMU) Islam.

Berdasarkan Undang-Undang Pendidikan Nasional tahun 1989, sekolah Islam harus mengikuti sistem sekolah negeri, maka sekolah Islam mengembil sepenuhnya kurikulum yang disusun dan dikeluarkan oleh Kemendiknas. Dengan demikian, tidak ada perbedaan antara Sekolah Islam dengan Sekolah umum (negeri). Yang membedakan mereka adalah, antara lain, penekanan khusus pada mata pelajaran (matpel) agama. Sekolah Islam memiliki jam matpel yang berhubungan dengan Islam lebih banyak, sehingga memiliki jam pelajaran lebih lama untuk matpel agama. Sekolah umum (negeri) juga mempunyai jam pelajaran agama dalam kurikulum mereka, karena matpel agama bersifat wajib dalam sisdiknas Indonesia, yang harus diajarkan sejak tingkat kanak-kanak hingga tingkat universitas. Hanya saja, pada sekolah umum (negeri), jam matpel agama sangatlah terbatas, yakni hanya dua jam per-minggu.

\section{Kemunculan Sekolah Islam dan Madrasah Elit \\ Dua dekade terakhir menunjukkan} bahwa lembaga pendidikan Islam tumbuh berkembang di berbagai wilayah Indonesia. Terdapat sejumlah success story (lompatan kemajuan) mengenai pendidikan Islam, baik dari sokongan kebijakan, peningkatan standard, perbaikan manajemen, kualitas raw input, kualitas proses, maupun peningkatan kualitas output. Bahkan tidak sedikit tulisan yang lahir mengenai "kiat membangun pendidikan favorit-unggulan bercorak Islam(i).

Meningkatnya peran Negara sebagai motor penggerak, yang secara gradual menggeser dominasi peran masyarakat, telah memunculkan dinamika baru dalam perkembangan "wajah" pendidikan Islam di Indonesia. Sebagian lembaga Pendidikan Islam tersebut terdiri dari
Madrasah dan Sekolah Islam. Munculnya sekolah dan madrasah, "elit" ini dapat juga menandai kebangkitan pendidikan Islam. Mulanya, sebagian lembaga pendidikan ini menamai dirinya sebagai "sekolah Islam" dan Madrasah saja. Namun, pada perjalanannya, sebagian dari mereka seiring dengan peningkatan pencitraan dan keterpercayaan public (public trust), sebagian sekolah Islam dan madrasah ini telah mengarah pada opini public sebagai "Sekolah Islam unggul(an)" dan "madrasah unggul(an)". Istilah lain untuk menggambarkan hal tersebut adalah "Sekolah Islam Model" dan "Madrasah Model".

Umumnya, lembaga pendidikan ini berdiri di perkotaan atau pun di wilayah pinggiran Kota. Karenanya Lembaga Pendidikan Islam kelompok ini dapat dikatakan sebagai fenomena kota atau fenomena masyarakat urban. Banyak orang tua muslim pada masyarakat urban dan kota yang menaruh perhatian lebih tentang pendidikan anak-anak mereka di sekolah Islam dan madrasah. Hal ini menstimulus para pendidik untuk memperbaiki kualitas manajemen dan kulitas layanan pendidikan mereka.

Beberapa faktor yang menumbuhkembangkan keberadaan sekolah dan madrasah elit ini. Pertama, kesadaran sebagian muslim untuk mendesain system pendidikan unggul, terlebih dari mereka yang pernah mengenyam pendidikan di luar negeri. Kedua, menurunnya tingkat kepercayaan sebagian masyarakat muslim terhadap proses dan hasil pendidikan di sekolah-sekolah umum (negeri atau swasta). Ketiga, skeptisnya sebagian masyarakat terhadap proses dan hasil pendidikan pada lembaga-lembaga pendidikan muslim yang ada [pesantren dan madrasah]. Keempat, peningkatan kemampuan ekonomi dari "kelas menengah muslim". Kelima, dukungan pemerintah dalam otonomi pendidikan swasta dan program pemerintah dalam 
upaya "internasionalisasi" semua level pendidikan di Indonesia.

Faktor "sokongan" pemerintah sangat signifikan pada dekade terakhir melalui kebijakan equivalensi madrasah dengan sekolah umum, dan terutama peningkatan alokasi anggaran. Lahirnya, UU Sisdiknas no. 20 tahun 2003, yang menghapus diskriminasi satuan pendidikan negeri dan swasta, sekolah dan madrasah, serta memasukkan diniyah dan pesantren dalam sistem pendidikan nasional, memaksa Negara mengubah haluan kebijakannya terhadap pendidikan Islam. Alokasi anggaran pendidikan dari Negara harus didistribusikan secara lebih adil dan proporsional.

Menguatnya keterlibatan Negara membawa warna tersendiri dalam konteks dinamika pendidikan Islam dan pemerataan akses pendidikan. Bahwa masyarakat muslim mempunyai akses yang lebih besar pada pendidikan Islam bermutu, yang menata manajemen dan sistem pendidikan berkualitas, dan lebih terbuka serta terjangkau oleh masyarakat, termasuk para pemangku kepentingan pendidikan, tanpa diskriminasi. ${ }^{20}$

Saat didominasi topangan elemen masyarakat, dan sokongan Negara masih bersifat minim, bukan berarti pendidikan Islam tidak memiliki dinamika dan capaian kualitas tinggi. Sebut saja, pesantren Gontor, sekalipun dikelola swadaya dan swadana, namun kualitas sistem pendidikannya diakui dunia internasional. Demikian pula dengan Universitas Islam Indonesia (UII) dan Universitas Muhammadiyah Yogyakarta (UMY), yang mempunyai reputasi nasional dan internasional. Hanya saja, capaian kualitas tersebut hanya berada pada beberapa madrasah, sekolah, atau pesantren tertentu saja.

\footnotetext{
${ }^{20}$ Asrori S. Karni, Etos Studi Kaum Santri, h.

Pada sisi lain, "sekolah Islam unggul [atau model]" dan "Madrasah Unggul [atau model]" ini dapat dikatakan sebagai "sekolah dan madrasah elit Islam", karena sejumlah alasan.

1. siswa-siswi yang masuk ke sekolah dan madrasah jenis ini terseleksi secara ketat, sehingga input siswanya memiliki kualitas akademis yang cukup, bahkan unggul.

2. tenaga kependidikan (kepala sekolah, tenaga administrasi, guru-guru, dan terkadang disertai psikolog] diseleksi secara ketat dan kompetitif, sehingga tenaga kependidikan yang memenuhi persyaratan yang ditetapkanlah yang ada di sekolah dan madrasah jenis ini.

3. Sistem pendidikan, terutama desain kurikulum dan proses implementasi kurikulum, yang diorientasikan untuk menciptakan [alumni] siswa yang memiliki multi-kecerdasan (multiply intelgences) dan berakhlakul karimah.

4. mereka memiliki sarana dan prasarana yang relatif lengkap, seperti laboratorium [bahasa, komputer], bengkel kerja, mesjid, dan sarana olah raga.

Secara akademis siswa dari sekolah dan madrasah unggul ini memiliki keunggulan input dibandingkan dengan sekolah dan madrasah yang sejenis, bahkan dengan sekolah dan madrasah yang dikelola oleh pemerintah. Kualitas proses pendidikan dan pembelajaran pun tidak kalah pentingnya untuk diperhatikan dari sekolah dan madrasah unggulan ini. Karena didukung oleh raw input yang bagus, maka umumnya proses pendidikan dan pembelajaran pun memiliki kualitas unggul pula. Pada akhirnya, kualitas output pun memiliki keungulan dibanding dengan output lembaga pendidikan sejenjang lainnya.

Sebab itu, sekolah Islam dan madrasah elit ini pada umumnya mahal. Selain baiaya pendaftaran, seleksi masuk, dan biaya bulanan, para orangtua juga 
harus membayar sejumlah besar uang yang bervariasi, yakni "biaya sumbangan" atau "uang pembangunan". Tambahan lainnya adalah biaya makan dan penginapan, jika sekolah atau madrasah tersebut merupakan sekolah atau madrasah asrama (bording school). Oleh karena itu, tidak semua orang tua muslim dapat menyekolahkan anak-anaknya di sekolah atau madrasah ini, kecuali melalui jalur beasiswa prestasi. Rata-rata siswanya berasal dari keluarga kaya atau elit, atau yang biasa disebut "kelas menengah muslim", yang mulai terbentuk sejak sekurang-kurangnya awal 1980-an berkat semakin membaiknya perekonomian Indonesia.

Pada sisi lain, sekolah Islam dan madrasah "elit" telah mampu menciptakan segmen "pasar pendidikan" tersendiri di tengah-tengah kompetisi pasar pendidikan global, baik dengan intra-lembaga pendidikan Islam, maupun dengan lembaga pendidikan lainnya, negeri atau swasta, di dalam negeri atau di luar negeri. Dengan demikian, sekolah Islam dan madrasah "elit" telah mampu menyajikan konsep dan sistem pendidikan sebagai "komoditas" yang dapat dikemas untuk menarik minat pembeli dan atau konsumen. Kompetisi "kualitas pendidikan" ini telah memungkinkan para orang tua untuk memilih lembaga pendidikan Islam yang lebih berkualitas dan lebih menguntungkan (secara moral, akademis, sosial, dan finasial) dari lembaga-lembaga pendidikan Islam yang saling bersaing.

Pada sisi ini pula, madrasah dan sekolah Islam "elit", disadari atau tidak, membuat kesenjangan sendiri berhadapan dengan madrasah dan sekolah ber"standar umum". Sebagian kalangan peserta didik dan orang tua menganggap bahwa siswa madrasah dan sekolah Islam elit berkesempatan mengenyam pendidikan mewah, berkualitas tinggi, dan sangat "berkelas", sementara siswa yang lain bersekolah di lembaga-lembaga pendidikan yang"kembang kempis" mempertahankan diri dalam berbagai aspek, yakni jumlah kelas minimal, biaya murah-meriah, guru "asal ada", dan manajemen tak "tertata rapi". Dengan kata lain, terdapa sejumlah lembaga pendidikan Islam yang besar dan makin besar, sementara yang kecil semakin kerdil dan menuju kepunahannya.

\section{Desain Unggul Sekolah Islam dan Madrasah Elit}

Sebuah sekolah dapat dikatakan sekolah unggul(an) atau sekolah model karena memberikan penekanan khusus dalam materi dan metode pembelajaran ilmu, pengetahuan, dan teknologi. Selain itu, keunggulan dari sebuah institusi pendidikan terletak pada menajeman kelembagaan yang dikelola secara professional. Karenanya, sekolah Islam dan madrasah unggul pun, memiliki kelebihan ini, secara umum mereka memiliki sejumlah perbedaan karakteristik dengan sekolah unggul(an) atau sekolah model yang dikelola Kemendiknas. Kelebihan lainnya, Sekolah Islam dan madrasah unggulan menambahkan penekanan lain pada religiusitas dan kesalehan melalui berbagai matpel keislaman. Secara sederhana, proses pendidikan yang dikembangkan di madrasah dan sekolah Islam bertujuan untuk mencetak alumni yang "cerdas" dan "berakhlak mulia".

Hal inilah yang mendorong para orang tua memasukkan anak-anaknya ke sekolah Islam dan madrasah. Fenomena ini merupakan perkembangan terbalik dari trend sebelumya. Di masa lalu, keluarga muslim yang kaya mengirimkan anak mereka ke sekolah-sekolah misionaris, baik Katolik maupun Protestan, yang sejak jaman Belanda dan hingga kini masih terkenal kualitasnya yang baik. Bahkan di kalangan orang tua muslim pernah ada semacam kebanggaan bila anak-anak mereka belajar di sekolah-sekolah misionaris. Hal ini menimbulkan pandangan bahwa belajar di sekolah- 
sekolah misionaris mempunyai gengsinya tersendiri.

Namun sekarang, para orang tua muslim memiliki sejumlah sekolah Islam dan madrasah sebagai alternatif yang baik untuk memperoleh pendidikan berkualitas bagi anak-anak mereka. Sekolah Islam dan madrasah elit ini menawarkan pendidikan bermutu dan memberikan prospek yang pasti bagi anak-anak mereka untuk melanjutkan pendidikan hingga ke jenjang pendidikan yang leboh tinggi. Siswa-siswi dari sekolan dan madrasah tersebut umumnya mampu bersaing dengan siswasisei dari sekolah negeri yang bagus dan dari sekolah-sekolah misionaris.

Banyak orang tua percaya bahwa dengan menyekolahkan anak-anaknya di sekolah Islam dan madrasah, anak-anaknya akan mendapat pandangan dan pemahaman yang lebih komprehensif mengenai Islam. Lebih dari itu, anak-anak mereka mendapatkan bimbingan dan didikan tentang pembiasaan praktik keislaman dalam kehidupan sehari-hari, seperti pembiasaan shalat berjama'ah, membaca dan memahami al-Qur'an, serta ketaatan dan kepatuhan terhadap orang tua.

Lebih jauh, para orang tua muslim pada umumnya percaya bahwa lingkungan sekolah dan madrasah lebih aman dibanding dengan lingkungan sekolah umum, terlebih sekolah Islam dan madrasah yang menerapkan sistem asrama. Misalnya, siswa-siswi sekolah Islam dan madrasah tidak pernah terdengar terlibat tawuran antarsiswa dari sekolah berbeda, sebagaimana dilakukan oleh siswa-siswi sekolah umum.

Madrasah dan sekolah Islam berasrama, bahkan yang mengadopsi sistem pesantren, memiliki sejumlah keunggulan lainnya. Aspek metode, kurikulum, dan manajemen diciptakan sebagai conditioning internalisasi nilainilai yang lebih paripurna. Sebab internalisasi nilai sangat bergantung pada lingkungan, selain pada pribadinya.
Beberapa nilai yang umumnya didapatkan dalam madrasah dan sekolah Islam berasrama (yang mengadopsi sistem pesantren) atau bersatu dengan pesantren adalah sebagai berikut. ${ }^{21}$

1. Pembiasaan dan pembentukan jiwa keikhlasan, yakni pembentukan jiwa yang selalu bergantung dan berserah diri kepada Allah, selalu mengharap ridha Allah dalam beraktivitas baik dan menjauhi segala keburukan serta tidak didorong oleh ambisi, keuntungan jangka pendek, atau popularitas, tetapi semata-mata karena Allah. Jiwa keikhlasan ini termanifestasikan dalam kehidupan sehari-hari dalam komunitas dan menjadi identitas para siswa (santri).

2. Pembiasaan dan pembentukan jiwa kesederhanaan, tetapi agung. Sederhana bukan berarti pasif, nrimo, dan miskin, tetapi mengandung unsur kekuatan dan ketabahan batin. Di balik kesederhanaan tersebut terkandung jiwa besar, keberanian, progressif, dan kreatif dalam menghadapi perkembangan dinamika social. Kesederhanaan menjadi identitas khas dari para siswa (santri) muslim.

3. Pembiasaan jiwa kemandirian, yakni berusaha sekuat tenaga untuk mampu hidup mandiri, baik untuk urusan pribadi maupun untuk kemajuan ummah. Para siswa (santri) tidak dididik untuk mengantungkan hidupnya kelak hanya menjadi pegawai (terutama PNS) tetapi juga ditanamkan jiwa wirausaha dan enterpereneuship. Siswa (santri) terbiasa menghadapi berbagai tekanan (persoalan) dan mencari solusi cerdasnya sendiri.

4. Pembiasaan dan pembentukan ukhuwah Islamiyyah yang demokratis. Situasi dialogis dan akrab antarkomunitas asrama (pesantren) yang

${ }^{21}$ Armai Arief, Tranformasi Pendidikan Islam, (Jakarta: CSRD Press, 2005), h. 50-51 
dipraktekkan sehari-hari, disadari atau tidak, akan mewujudkan suasana damai, serta senasib dan sepenanggungan yang dapat membantu pembentukan dan pengembangan idealism kolektif para siswa (santri). Perbedaan kulur, primordialisme, suku, ras, dan status social (orang tuanya), tidak menjadi jalangan untuk membentuk jalinan pertemanan dan persaudaraan yang dilandasi oleh spiritualitas Islam yang tinggi.

5. Pembiasaan dan pembentukan jiwa yang "bebas" (tidak terlalu bergantung pada yang lain) atau bebas tekanan "politis", dan optimistik terhadap berbagai persoalan yang dihadapi.

Di madrasah dan sekolah Islam tidak terdapat diskriminasi gender. Siswa lakilaki dan perempuan diposisikan secara sama (equality), yakni mempunyai kesempatan yang sama untuk mendapatkan ilmu, pengetahuan, teknologi, dan seni (ipteks). Keduanya dapat bersaing untuk mendapatkan prestasi setinggi-tingginya, tanpa melalaikan kodrat masing-masing. Selain keduanya dipersiapkan untuk menghadapi berbagai kesempatan dan hambatan di wilayah publik (pekerjaan dan pemerintahan), mereka juga dipersiapkan dengan berbagai keilmuan yang beroreientasi pada keluarga. Pada aspek pengetahuan "berkeluarga" ini, pendidikan madrasah dan sekolah Islam memperkenalkan berbagai ilmu untuk membangun keluarga sakinah mawaddah wa rahmah. Jelas materi ini tidak banyak ditemui di sekolah umum.

Dengan segala keunggulan desain pendidikan yang dimiliki sekolah Islam dan madrasah elit seperti di atas, maka tidaklah heran jika keberadaan mereka semakin menanjak popularitasnya. Dengan demikian, berbeda dengan situasi pada masa penjajahan Belanda, masa orde lama, dan masa orde baru, di mana banyak kaum muslim yang malu, bahkan menutupi identitas kemuslimannya, kini banyak kaum muslim yang bangga dengan identitas kemuslimannya. Sebagaimana dikatakan Nakamura bahwa Islam tengah menjadi identitas yang dibanggakan, sesuatu yang indah. Keberadaan sekolah Islam dan madrasah elit tidak hanya menjadi simbol dari kebanggaan muslim tentang lembaga pendidikannya, tetapi juga menjadi wahana pendidikan bagi generasi penerus agar bangga menjadi umat Islam.

Equivalensi antara madrasah dan sekolah Islam dengan sekolah umum, pada sisi lain, memunculkan sejumlah konsekuensi yang tidak diharapkan (unintended consequences) dan tidak mudah dicarikan solusinya. Misalnya, penerapan equibalensi tersebut mengharuskan madrasah dan sekolah Islam menerapkan kurikulum sekolah umum yang ditetapkan oleh Kementrian Pendidikan Nasional, dari mulai kurikulum 1994 hingga Kurikulum Tingkat Satuan Pendidikan (KTSP). Pada sisi lain, untuk memelihara"karakter pendidikan Islam", madrasah dan sekolah Islam harus memiliki bobot mata pelajaran agama lebih banyak. Hasilnya, beban pelajaran secara keseluruhan di madrasah dan sekolah Islam, umumnnya, lebih berat dibandingkan sekolah umum.

Konsekuensi lebih berdampak luas lainnya adalah pada tingkat MA, jurusanjurusan yang dikembangkan juga mengikuti pola penjurusan yang ada di SMU, khususnya IPA, IPS, dan Bahasa. Hasilnya, jurusan-jurusan inilah yang kemudian dominan di MA, termasuk MA yang ada di Pesantren. Bahkan kemudian juga popular MA yang lebih menekankan pada keterampilan (vicasional), sehingga lebih merupakan vocational school). Yang tragis, sebagaimana telah disinggung, adalah nasib dari MAPK, madrasah yang awalnya diprioritaskan menjadi unggulan MA, kini termarjinalkan. Apalagi ketika MAPK ini tidak terdapat dalam nomenklatur UU Sisdiknas tahun 1989 dan 2003. Lebih jauh lagi, pada tahun yang 
lalu, Departemen Agama RI menghapuskan MAPK dan menjadikannya sebagai jurusan belaka pada sistem MA yang telah didominasi jurusan-jurusan umum. Azyumardi Azra menyebutkan bahwa hal ini merupakan indicator dari marginalisasi tafaqquh fi al-dîn pada tingkat MA yang menimbulkan dampak luar biasa terhadap perguruan tinggi Islam. $^{22}$

Dalam kondisi seperti ini madrasah dan sekolah Islam yang berasrama memiliki sistem yang cukup memadai untuk pencapaian tafaqquh fi al-dîn. Beban kurikulum madrasah, apalagi sekolah Islam, dapat ditunjang dengan pembelajaran keislaman di pesantren atau asrama. Namun, hal yang tidak mudah juga untuk menyinergikan kurikulum madrasah dan sekolah Islam, dengan kurikulum pesantren atau asrama, karena beberapa hal. Pertama, perbedaan orientasi kurikulum madrasah dan sekolah Islam dengan pesantren atau asrama. Madrasah dan sekolah Islam mengejar materi dan kurikulum yang dipatok pemerintah, sementara pesantren dan sekolah Islam mengejar materi dan kurikulum pesantren. Kedua, pengelola dan pengajar pada keduanya terkadang berbeda, yang juga membedakan susut pandang dan metode pengejaran, termasuk pencapaian kompetensi peserta didik. Bahkan tidak sedikit ditemukan sejumlah "friksi" antara pengelola pesantren (dan asrama) dengan pengelola madrasah dan sekolah Islam.

\section{E. Kesimpulan}

Sekolah Islam dan madrasah unggulan menambahkan penekanan pada religiusitas dan kesalehan melalui berbagai matpel keislaman. Secara sederhana, proses pendidikan yang dikembangkan di madrasah dan sekolah Islam bertujuan untuk mencetak alumni yang "cerdas" dan "berakhlak mulia". Faktor yang menumbuhkembangkan keberadaan sekolah dan madrasah elit; kesadaran sebagian muslim untuk mendesain system pendidikan unggul, menurunnya proses dan hasil pendidikan di sekolah-sekolah umum, skeptisnya sebagian masyarakat terhadap proses dan hasil pendidikan pada lembaga-lembaga pendidikan muslim yang ada [pesantren dan madrasah].Peningkatan kemampuan ekonomi dari "kelas menengah muslim", dukungan pemerintah dalam otonomi pendidikan swasta dan program pemerintah dalam upaya "internasionalisasi" semua level pendidikan di Indonesia.

\section{DAFTAR PUSTAKA}

Asrori S. Karni, Etos Studi Kaum Santri: Wajah Baru Pendidikan Islam, (Bandung: Mizan, 2009),

Azyumardi Azra, Pendidikan Islam: Tradisi dan Modernisasi Menuju Milenium Baru, (Jakarta: Logos, 2003), cetakan ke-5.

Asrori S. Karni, Etos Studi Kaum Santri: Wajah Baru Pendidikan Islam, (Bandung: Mizan, 2008),

Robert W. Hefner dan Qasim Zaman (ed), Schooling Islam, The Culture and Politics of Modern Islamic Education, (Princeton University Press, 2007).

Mumtaz Ahmad dalam "Madrasah Reform and Perspectives: Islamic Tertiary Education in Pakistan" dan "Views Form Madrasah: Islamic Education in Bangladesh" (NBR Project Report, 2009).

Virginia Hooker, "New Undestanding of Islamic Education in Indonesia", dalam Asrori S. Karni, Etos Studi Kaum Santri: Wajah Baru Pendidikan Islam, (Bandung: Mizan, 2008) 
Model Pembelajaran Kooperatif Perspektif Al-Qur'an

Rausyan Fikr. Vol. 15 No.1 Maret 2019. ISSN. 1979-0074 e-ISSN. $9772580594187 \mid 42$ 